\title{
Experimental study of effect additional water on high performance geopolymer concrete
}

\author{
Rachmansyah ${ }^{1, *}$, Harianto Hardjasaputra ${ }^{2}$, and Meilanie Cornelia ${ }^{2}$ \\ ${ }^{1}$ Civil Engineering Department, Krida Wacana Christian University, Jakarta, Indonesia \\ ${ }^{2}$ Civil Engineering Department, Pelita Harapan University, Tangerang, Indonesia
}

\begin{abstract}
The Earth Summit 1997 in Kyoto (Japan), industrialized countries agreed to reduce gas emissions by $21 \%$ to avoid global warming due to greenhouse effect with the release of $\mathrm{CO}_{2}$ into the air. From the research result, cement industry sector all over the world contributes about 8 $10 \%$ of total $\mathrm{CO}_{2}$ emission. This number is quite high and if there is not a special action to reduce, $\mathrm{CO}_{2}$ emissions will continue to increase along with the rapid development of infrastructure in various parts of the world including in Indonesia. To support greenhouse effect reduction efforts due to $\mathrm{CO}_{2}$ emissions and environmental conservation, civil engineers in the world are taking steps to achieve Sustainable Concrete Technology, in order to create "Green Concrete". For that reason in the direction of "Green Concrete", innovation is needed to reduce or replace cement in the concrete mixing. The ash waste electrical power generating plants of fly ash is a material containing many $\mathrm{SiO}_{2}$ and $\mathrm{Al}_{2} \mathrm{O}_{3}$ which can be used to replace the overall of cement in concrete. Geopolymer concrete is a fly ash-based concrete that replaces the entire cement in its manufacture. Workability in mixing geopolymer concrete is very low, due to the rapid reaction of the alkaline solution when it reacts with fly ash. To improve the workability can be added water at the time of mixing. The fly ash used in the mixing from the Paiton power plant in East Java with grain size $12.06 \mu \mathrm{m}$ with round granules and chemical composition of fly ash containing $\mathrm{SiO} 2$, $\mathrm{Al} 2 \mathrm{O} 3$ and $\mathrm{Fe} 2 \mathrm{O} 3$ with a total of $75.151 \%$. The planned compressive strength of the concrete is $45 \mathrm{MPa}$, with a variation of $8 \mathrm{M}, 12 \mathrm{M}$ and $16 \mathrm{M} \mathrm{NaOH}$ molarity and the ratio of $\mathrm{NaOH}$ and $\mathrm{Na} 2 \mathrm{SiO} 3$ is 1 . Addition of water in concrete mixing with variations of 15, 17.5, 20, 22.5 and 25 liters / m3. The results of this study indicate that the more addition of water in the manufacture of geopolymer concrete can also increase the value of slump, but the excessive addition of water will result in a decrease in the compressive strength of the concrete caused by a decrease in the concentration of the alkaline solution. High molarity values will require additional water to reach the same slump value compared to lower $\mathrm{NaOH}$ molarity. With the same mix design, the optimal compressive strength at $8 \mathrm{M} \mathrm{NaOH}$ was $48.18 \mathrm{MPa}$ with $17.5 \mathrm{liters} / \mathrm{m}^{3}$ of water added with a slump of $12 \mathrm{~cm}$, for $12 \mathrm{M} \mathrm{NaOH}$ the optimal compressive strength was $51.65 \mathrm{MPa}$ with the addition of $20 \mathrm{liter} / \mathrm{m}^{3}$ with $10 \mathrm{~cm}$ slump, while for $16 \mathrm{M} \mathrm{NaOH}$ the optimum compressive strength is $59.70 \mathrm{MPa}$ with 22.5 liters $/ \mathrm{m}^{3}$ of water added with a $5 \mathrm{~cm}$ slump. The higher the $\mathrm{NaOH}$ molarity will result in a higher compressive strength value and geopolymer concrete compressive strength at early age is higher than conventional concrete.
\end{abstract}

\section{Introduction}

The Earth Summit 1997 in Kyoto (Japan), industrialized countries agreed to reduce gas emissions by $21 \%$ to avoid global warming due to greenhouse effect with the release of $\mathrm{CO} 2$ into the air. From the research result, cement industry sector all over the world contributes about 8 $10 \%$ of total $\mathrm{CO}_{2}$ emission. This number is quite high and if there is not a special action to reduce, $\mathrm{CO}_{2}$ emissions will continue to increase along with the rapid development of infrastructure in various parts of the world including in Indonesia, which requires a lot of cement as a component of concrete building materials.
To support efforts to reduce greenhouse effects due to $\mathrm{CO} 2$ emissions and environmental conservation, civil engineers in the world take steps to achieve Sustainable Concrete Technology, so that Green Concrete can be created. Green Concrete is a philosophical understanding, not a literal understanding. Now, concrete is the most widely used construction material and is needed in infrastructure development, but also realized as a material that has a major contribution to global warming and has a bad impact on environmental conservation. For this reason, it is necessary to take appropriate steps so that concrete can become a "sustainable construction material", namely as a construction material which, from

\footnotetext{
* Corresponding author: rachmansyah@ukrida.ac.id
} 
the production process, during the use of the structure, and even after being waste, can continue to run in harmony with the global program for protection and preservation environment.

To support the "Green Concrete" we can take the following actions:

1. Reducing the use of cement in concrete mix designs, with substitution of other pozzolanic substances

2. Looking for new materials to replace cement, where the production process requires low energy;

With these two actions, it is expected that concrete will become a "sustainable construction material". The reduction of cement in the manufacture of concrete can be done by using a partial or whole substitute of cement in concrete which is pozzolanic which contains a lot of $\mathrm{SiO} 2$, such as fly ash which is a waste next to the Steam Coal Power Plant. In addition to reducing the use of cement in the manufacture of concrete, a step that can be done is to look for new materials to replace cement. Geopolymers are environmentally friendly materials that can be used to replace cement in the manufacture of concrete. Geopolymers are more environmentally friendly, because the main material is fly ash which is an industrial waste of Steam Coal Power Plant, besides that in the manufacturing process it only requires low energy at a temperature of $750{ }^{\circ} \mathrm{C}$, unlike in the manufacture of cement which requires large energy up to $1400{ }^{\circ} \mathrm{C}$.

Steam Coal Power Plants in Indonesia still dominate the power generation system and the number will increase along to support the $35,000 \mathrm{MW}$ government program. The various types of power plants in Indonesia will increase coal consumption, based on the 2016 electricity statistics issued by the Directorate General of Electricity of the Ministry of Energy and Mineral Resources of the Republic of Indonesia in early 2017. In Figure 1 it can be seen that Coal Increase in Indonesia from 2009 to 2016.

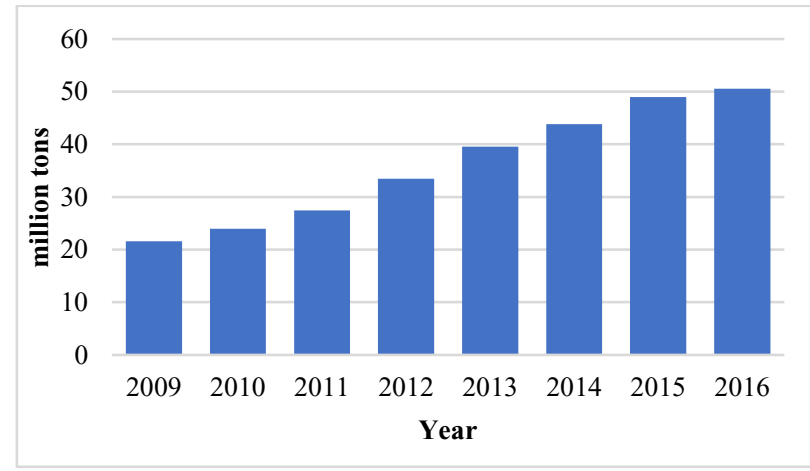

Fig. 1. Coal Consumption in steam coal power plants

Increased use of coal will cause problems to increase coal waste generated during the burning process at the power plant. Waste generated from coal combustion is $5 \%$ of coal volume. In 2016, the power plant in Indonesia consumed 50 million tons will produce coal waste of 2.5 million tons and will increase along with the increasing number of power plants in Indonesia. Coal waste is included as a hazardous and toxic waste material that must be specifically managed so as not to cause environmental damage. Management of coal waste at the power plant is done by landfilling and use in the construction field in making concrete even though on a small scale. The construction industry must be encouraged to increase the utilization of coal waste in the manufacture of concrete as an effort to reduce the environmental impacts that occur due to hoarding, besides that coal waste also has high economic value compared to cement. Utilization of coal waste in making concrete by replacing part or all of the cement in concrete.

Concrete Geopolymer made from fly ash are formed from polymerization reactions due to alkalialuminosilicate reactions that produce strong structural materials such as zeolites [1]. The alkaline solution commonly used is a mixture of $\mathrm{Na} 2 \mathrm{SiO} 3$ and $\mathrm{NaOH}$, this alkaline solution as an activator that reacts with silica minerals and alumina. Geopolymer concrete can achieve fc '50 MPa concrete compressive strength with flexural strength for 7.7 MPa [2]. From the results of these studies indicate that the geopolymer concrete (non -cement) produced can be used as structural concrete.

In the manufacture of geopolymer concrete, the reaction of alkaline solutions with fly ash is faster than the manufacture of cement-based concrete, making the workability level in the manufacture of geopolymer concrete very low. Due to the fast setting time, the concrete mix should be poured as soon as possible into the mold after the mixture is evenly mixed. For increased workability in the manufacture of concrete, water can be added to the manufacture of geopolymer concrete. The increasing use of water in the manufacture of geopolymer concrete will increase manufacturing workability but will result in lowering the compressive strength of the concrete. In this study an experimental study was conducted to determine the effect of adding water to the compressive strength of geopolymer concrete.

\section{Geopolymer concrete}

Geopolymer concrete is concrete made from fly ash formed from polymerization reactions due to alkalialuminosilicate reactions that produce strong structured materials such as zeolites [1]. The alkaline solution commonly used is a mixture of $\mathrm{Na} 2 \mathrm{SiO} 3$ and $\mathrm{NaOH}$, this alkaline solution as an activator that reacts with silica minerals and alumina. Natural minerals that can be used such as kaolin, clay, mica, andalusite, spinel and so on. Other alternatives that can be used are byproducts / waste such as fly ash, silica fume, slag, rice husk ash, red mud and so on. From the many studies that have been done, geopolymer concrete has many advantages from conventional concrete that uses cement, among others, has high initial strength, low shrinkage, freeze-thaw resistance, sulfate resistance, corrosion resistance, acid resistance, resistance against fire and harmless alkali aggregate reactions. In addition to having many advantages from conventional concrete, geopolymer concrete also has several disadvantages such as low workability and manufacturing prices are still relatively expensive, especially in the price of alkaline solutions.

The development of geopolymer in the world is very rapid which can be seen in 2014, the use of geopolymer is quite massive around 40,000 $\mathrm{m} 3$ for apron pavement and 
taxiway at Brisbane West Wellcamp [3]. The airport construction project is the construction that uses the world's largest geopolymer concrete which is carried out by Wagners Company. Whereas in Indonesia many studies have been conducted by academics, one of them by Harianto Hardjasaputra and Esteriana Ekawati in 2017 which produced compressive strength geopolymer concrete reaching fc '50 MPa and flexural strength fcr 7.7 $\mathrm{MPa}$ [2]. The results of this study indicate that the geopolymer concrete produced can be used as structural concrete.

\section{Materials}

Geopolymer concrete materials consist of 3 main materials including fly ash (as a substitute for cement in conventional concrete), aggregate (coarse and fine) and alkaline solution ( $\mathrm{Na} 2 \mathrm{SiO} 3$ and $\mathrm{NaOH}$ as activators).

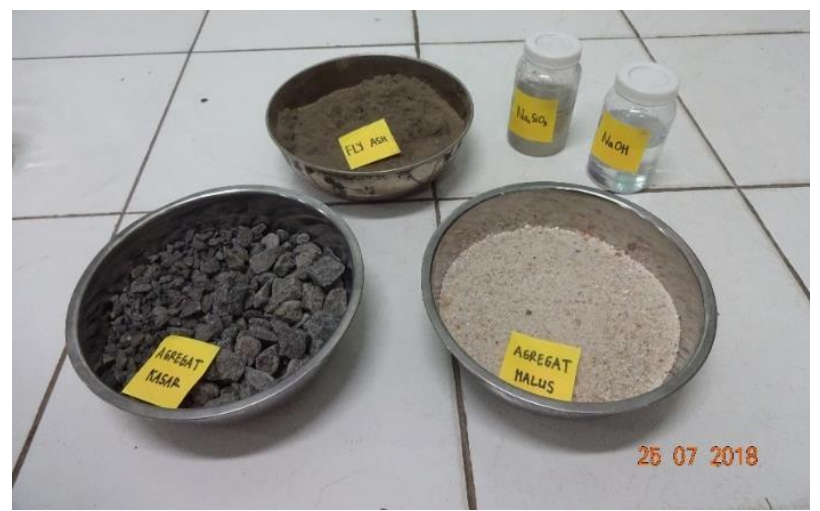

Fig. 2. Geopolymer concrete materials

\subsection{Fly ash}

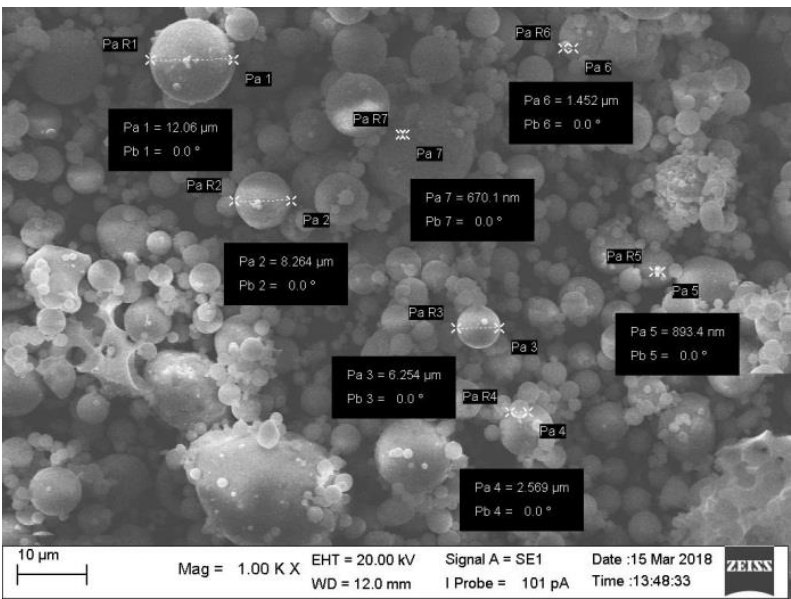

Fig. 3. SEM result

The fly ash used in the mixing from the Paiton power plant in East Java. To determine the size of the granules and the shape of the fly ash Scanning Electron Microscope (SEM) was tested and to determine the chemical composition X-Ray Fluorescence (XRF) was tested. The results of SEM testing showed that the maximum fly ash grain size was $12.06 \mu \mathrm{m}$ with round granules. XRF test results show the chemical composition of fly ash containing $\mathrm{SiO} 2, \mathrm{Al} 2 \mathrm{O} 3$ and $\mathrm{Fe} 2 \mathrm{O} 3$ with a total of $75.151 \%$, meaning that the fly ash tested can be categorized as class F fly ash based on ASTM C 618. This fly ash containing higher $\mathrm{CaO}$ will increase compressive strength at an early age but will accelerate the hardening of the concrete [4].

Table 1. Chemical analysis of fly ash

\begin{tabular}{|c|c|}
\hline Compound Name & Concentration (\%) \\
\hline $\mathrm{SiO} 2$ & 37,385 \\
\hline $\mathrm{Fe} 2 \mathrm{O} 3$ & 25,223 \\
\hline $\mathrm{CaO}$ & 14,084 \\
\hline $\mathrm{A} 12 \mathrm{O} 3$ & 12,543 \\
\hline $\mathrm{K} 2 \mathrm{O}$ & 3,474 \\
\hline $\mathrm{TiO} 2$ & 2,757 \\
\hline $\mathrm{P} 2 \mathrm{O} 5$ & 1,638 \\
\hline Compound Name & Concentration (\%) \\
\hline $\mathrm{MgO}$ & 0,855 \\
\hline $\mathrm{SO} 3$ & 0,853 \\
\hline $\mathrm{BaO}$ & 0,349 \\
\hline $\mathrm{SrO}$ & 0,275 \\
\hline $\mathrm{Na} 2 \mathrm{O}$ & 0,173 \\
\hline $\mathrm{ZrO} 2$ & 0,144 \\
\hline $\mathrm{ZnO}$ & 0,121 \\
\hline $\mathrm{Cl}$ & 0,048 \\
\hline $\mathrm{Rb} 2 \mathrm{O}$ & 0,045 \\
\hline $\mathrm{Br}$ & 0,016 \\
\hline $\mathrm{Y} 2 \mathrm{O} 3$ & 0,015 \\
\hline
\end{tabular}

\subsection{Aggregate}

The coarse aggregate used is crushed stone with a maximum size of $25 \mathrm{~mm}$ which has a specific gravity of 2.47. While the fine aggregate uses natural sand with a maximum size of $4.75 \mathrm{~mm}$ with a specific gravity of 2.53 .

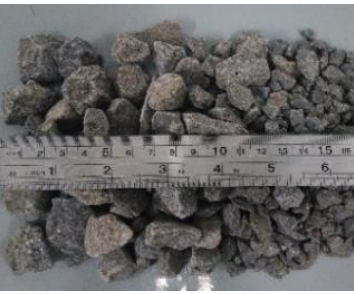

(a)

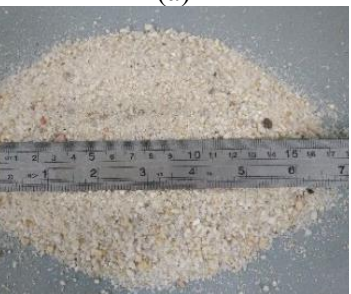

(b)

Fig. 4. Crushed aggregat (a) and natural sand (b)

\subsection{Alkaline solution}

The activator/alkali solution used in mixing geopolymer concrete is a combination of $\mathrm{NaOH}$ (sodium hydroxide) 
and $\mathrm{Na} 2 \mathrm{SiO} 3$ (sodium silicate). In mixing geopolymer concrete, $\mathrm{NaOH}$ molarity consists of $8 \mathrm{M}, 12 \mathrm{M}$ and $16 \mathrm{M}$.

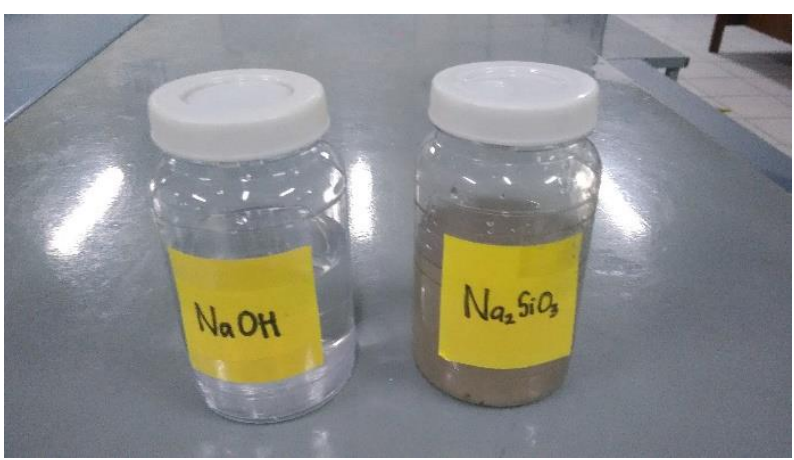

Fig. 5. Alkali solution

\section{Mixed design}

Because there is no standard used for the design of mixtures on geopolymer concrete. For this research, the design of geopolymer concrete mix will use SNI 03-64682000 [5] as the initial reference mixture. The results of the design will be used as the initial design for the manufacture of geopolymer concrete by modifying or replacing the overall cement with fly ash and water with alkaline solutions $\left(\mathrm{NaOH}\right.$ and $\left.\mathrm{Na}_{2} \mathrm{SiO}_{3}\right)$.

The planned geopolymer concrete quality is $45 \mathrm{MPa}$ with a slump of 75-100 mm, maximum aggregate size of $25 \mathrm{~mm}$, specific gravity of coarse aggregate 2.47 and fine aggregate 2.53, weight of coarse aggregate content of $1565.0 \mathrm{~kg} / \mathrm{m} 3$ and fine aggregate $1603.5 \mathrm{~kg} / \mathrm{m} 3$, density of fly ash 2.6, specific gravity of $\mathrm{NaOH} 1.4$ and $\mathrm{Na} 2 \mathrm{SiO} 3$ 1.6. Can be seen in table 2, the results of geopolymer concrete mix design design by modifying the results of normal concrete mix designs (SNI 03-6468-2000).

Table 2. Proportion of Geopolymer Concrete Mixtures

\begin{tabular}{|l|r|r|}
\hline \multicolumn{1}{|c|}{ Material } & \multicolumn{1}{|c|}{$\begin{array}{c}\text { Normal } \\
\text { Concrete } \\
(\mathbf{k g} / \mathbf{m} 3)\end{array}$} & \multicolumn{1}{c|}{$\begin{array}{c}\text { Geopolimer } \\
\text { Concrete } \\
(\mathbf{k g} / \mathbf{m} 3)\end{array}$} \\
\hline Cement & 546,17 & - \\
\hline Flyash & - & 546,17 \\
\hline Coarse Aggregate & 1173,75 & 1173,75 \\
\hline Fine Aggregate & 381,30 & 443,71 \\
\hline Water & 185,70 & - \\
\hline $\mathrm{NaOH}$ & - & 92,85 \\
\hline $\mathrm{Na} 2 \mathrm{SiO} 3$ & - & 92,85 \\
\hline
\end{tabular}

In the manufacture of geopolymer concrete several variations of $\mathrm{NaOH}$ molarity from $8 \mathrm{M}, 12 \mathrm{M}$ and $16 \mathrm{M}$ were carried out and additional water variations from 15.0 - 27.5 1/m3 which can be seen in tables 3, 4 and 5 .

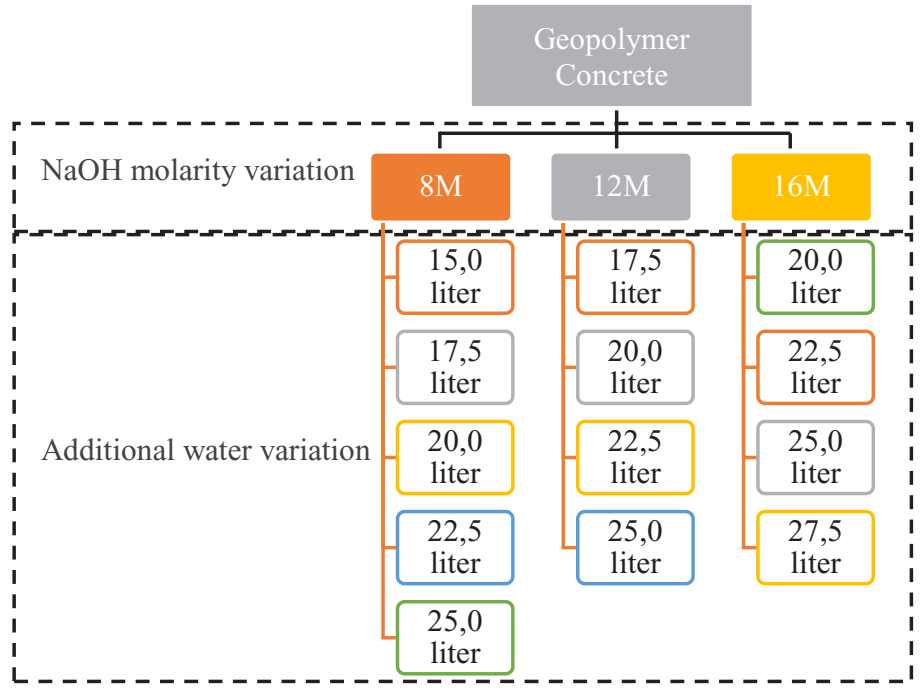

Fig. 6. Mix design variation

Table 3. Proportion of Geopolymer Concrete Mixtures ( $\mathrm{NaOH} 8 \mathrm{M})$

\begin{tabular}{|l|r|r|r|r|r|}
\hline & \multicolumn{1}{|c|}{ 45E1 } & \multicolumn{1}{|c|}{ 45E2 } & \multicolumn{1}{|c|}{ 45E3 } & \multicolumn{1}{c|}{ 45E4 } & \multicolumn{1}{c|}{ 45E5 } \\
\hline Flyash & 546,17 & 546,17 & 546,17 & 546,17 & 546,17 \\
\hline $\begin{array}{l}\text { Coarse } \\
\text { Aggregate }\end{array}$ & 1155,23 & 1152,14 & 1149,05 & 1145,96 & 1142,88 \\
\hline $\begin{array}{l}\text { Fine } \\
\text { Aggregate }\end{array}$ & 424,74 & 421,58 & 418,41 & 415,25 & 412,09 \\
\hline $\mathrm{NaOH}$ & 92,85 & 92,85 & 92,85 & 92,85 & 92,85 \\
\hline $\mathrm{Na} 2 \mathrm{SiO} 3$ & 92,85 & 92,85 & 92,85 & 92,85 & 92,85 \\
\hline Water & 15,00 & 17,50 & 20,00 & 22,50 & 25,00 \\
\hline
\end{tabular}

Table 4. Proportion of Geopolymer Concrete Mixtures ( $\mathrm{NaOH} 12 \mathrm{M})$

\begin{tabular}{|l|r|r|r|r|}
\hline & 45F1 & 45F2 & 45F3 & 45F4 \\
\hline Flyash & 546,17 & 546,17 & 546,17 & 546,17 \\
\hline $\begin{array}{l}\text { Coarse } \\
\text { Aggregate }\end{array}$ & 1152,14 & 1149,05 & 1145,96 & 1142,88 \\
\hline $\begin{array}{l}\text { Fine } \\
\text { Aggregate }\end{array}$ & 421,58 & 418,41 & 415,25 & 412,09 \\
\hline $\mathrm{NaOH}$ & 92,85 & 92,85 & 92,85 & 92,85 \\
\hline $\mathrm{Na} 2 \mathrm{SiO3}$ & 92,85 & 92,85 & 92,85 & 92,85 \\
\hline Water & 17,50 & 20,00 & 22,50 & 25,00 \\
\hline
\end{tabular}

Table 5. Proportion of Geopolymer Concrete Mixtures $(\mathrm{NaOH} 16 \mathrm{M})$

\begin{tabular}{|l|r|r|r|r|}
\hline & \multicolumn{1}{|c|}{ 45G1 } & \multicolumn{1}{c|}{ 45G2 } & \multicolumn{1}{c|}{ 45G3 } & \multicolumn{1}{c|}{ 45G4 } \\
\hline Flyash & 546,17 & 546,17 & 546,17 & 546,17 \\
\hline $\begin{array}{l}\text { Coarse } \\
\text { Aggregate }\end{array}$ & 1149,05 & 1145,96 & 1142,88 & 1139,79 \\
\hline $\begin{array}{l}\text { Fine } \\
\text { Aggregate }\end{array}$ & 418,41 & 415,25 & 412,09 & 408,93 \\
\hline $\mathrm{NaOH}$ & 92,85 & 92,85 & 92,85 & 92,85 \\
\hline $\mathrm{Na} 2 \mathrm{SiO} 3$ & 92,85 & 92,85 & 92,85 & 92,85 \\
\hline Water & 20,00 & 22,50 & 25,00 & 27,50 \\
\hline
\end{tabular}

\section{Mixing and curring}

Mixing and curing of geopolymer concrete can be seen in tabel 6. 
Table 6. Mixing and curing procedure

\begin{tabular}{|c|c|l|}
\hline Step & Time & \multicolumn{1}{|c|}{ Procedure } \\
\hline 1 & $0-3$ & $\begin{array}{l}\text { Mix the alkaline solution }(\mathrm{NaOH}, \\
\text { Na2SiO3) and additional water until } \\
\text { evenly distributed in the bucket }\end{array}$ \\
\hline 2 & $3-8$ & $\begin{array}{l}\text { Mix the fly ash in an alkaline solution } \\
\text { until evenly distributed }\end{array}$ \\
\hline 3 & $8-10$ & $\begin{array}{l}\text { Add coarse aggregate and fine aggregate } \\
\text { to the mixer and mix until evenly } \\
\text { distributed }\end{array}$ \\
\hline 4 & $10-20$ & $\begin{array}{l}\text { Add the geopolymer paste into the mixer } \\
\text { and mix it evenly with the aggregate }\end{array}$ \\
\hline 5 & - & \begin{tabular}{l} 
Slump test \\
\hline 6
\end{tabular} \\
\hline 7 & -22 & $\begin{array}{l}\text { Mix the mixture before put it in the mold } \\
\text { The mixture inserted into the mold and } \\
\text { compacted }\end{array}$ \\
\hline 8 & - & $\begin{array}{l}\text { Curing concrete on the oven at } 60-70{ }^{\circ} \mathrm{C} \\
\text { for } 24 \pm 4 \text { hours }\end{array}$ \\
\hline
\end{tabular}
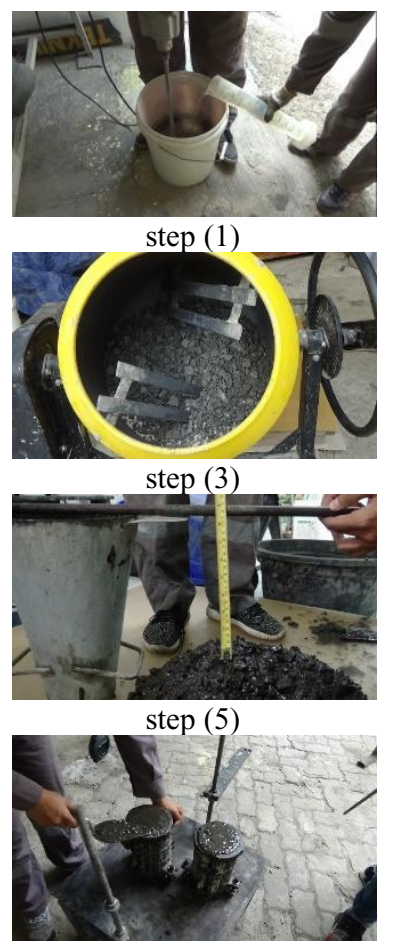

step (7)

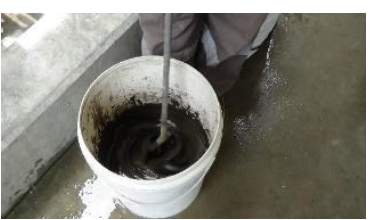

step (2)
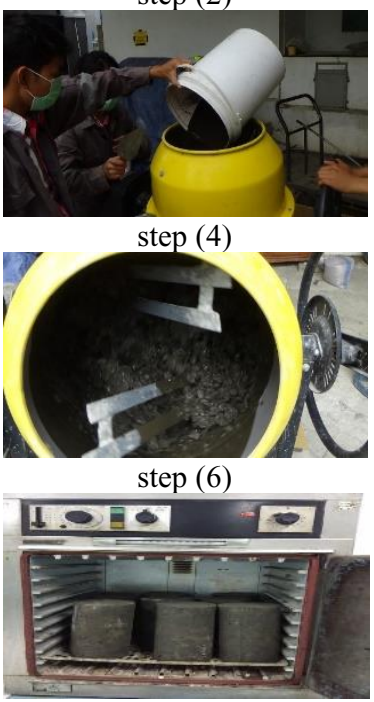

$\operatorname{step}(8)$

Fig. 7. Mixing and curing procedure

\section{Concrete testing}

There are two tests on concrete, slump to test the workability of fresh concrete and crushing test to determine the compressive strength of concrete.

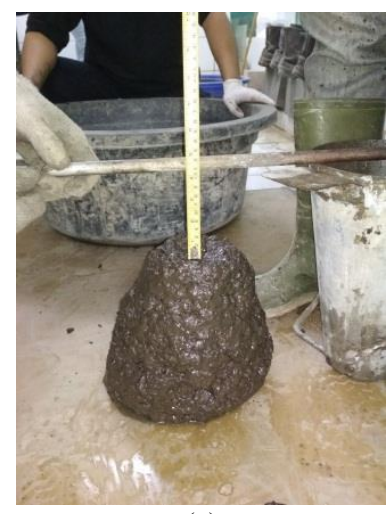

(a)

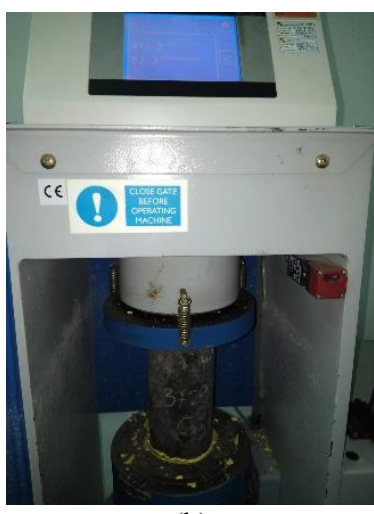

(b)
Fig. 8. Slump test (a) Crushing test (b)

\section{Result}

\subsection{Effect of slump value with addition of water}

The slump obtained when mixing increases with the increase of additional water. The higher the $\mathrm{NaOH}$ molarity value requires the addition of more water to reach the desired slump. In figure 9 , it can be seen the value of slump with various additional water and different molarity of $\mathrm{NaOH}$.

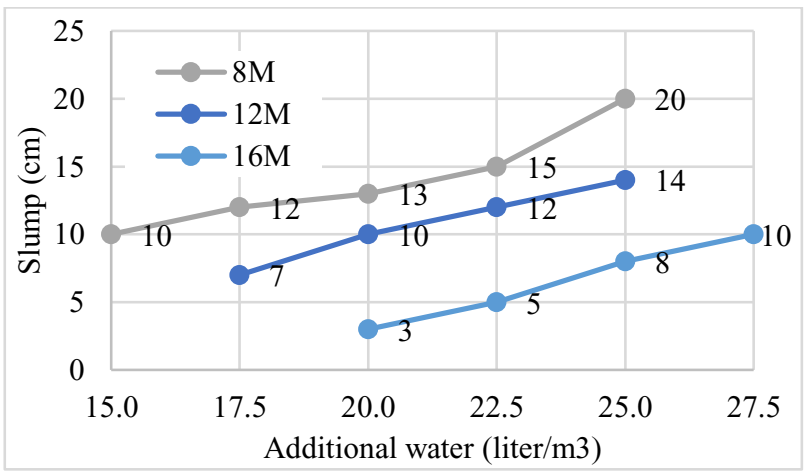

Fig. 9. Relation between additional water, slump and molarity of $\mathrm{NaOH}$

\subsection{Relationship between value of compressive strength and addition of water and molarity of naoh}

The additional of water with a certain limit in the mixing of geopolymer concrete effects with increased the compressive strength, but the excessive additional water will lead to decreases of compressive strength. The maximum compressive strength for geopolymer concrete with $\mathrm{NaOH} 8 \mathrm{M}$ is $48.18 \mathrm{MPa}, 12 \mathrm{M}$ is $51,65 \mathrm{MPa}$ and $16 \mathrm{M}$ is $59,70 \mathrm{MPa}$. Increased molarity of $\mathrm{NaoH}$ will increased compressive strength. In figure 10, it can be seen the value of compressive strength with various additional water and different molarity of $\mathrm{NaOH}$. 


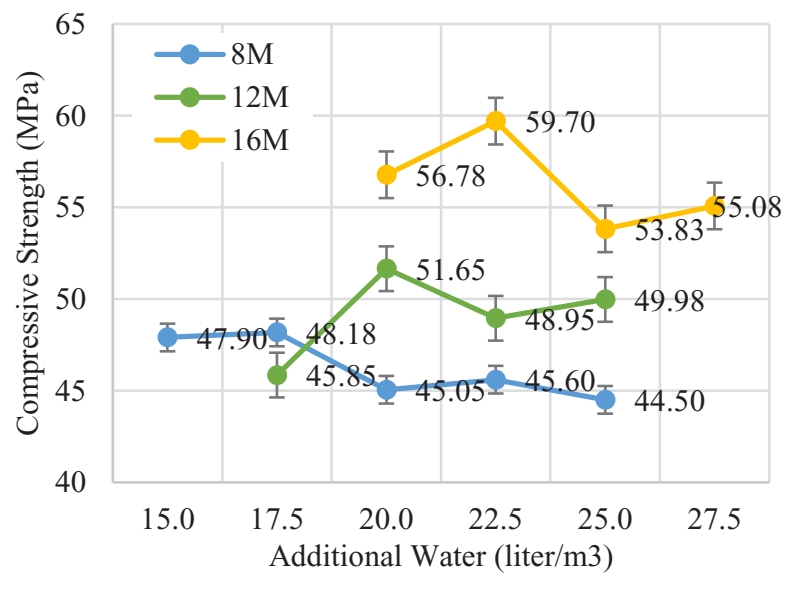

Fig. 10. Relation between additional water, compressive strength and molarity of $\mathrm{NaOH}$

\subsection{Increasing geopolymer compressive strength to test age}

concrete

Geopolymer concrete has a high compressive strength compared to normal concrete in early age. Increasing the compressive strength of geopolymer concrete against the age of testing can be seen in figure 11. The compressive strength of geopolymer concrete at 3 days old was $76.08 \%$, age 7 days $84.60 \%$ and 14 days $91.58 \%$ from compressive strength 28 days. The increase in the initial compressive strength of geopolymer concrete can occur because the concrete gets curing at a temperature of 60$70{ }^{\circ} \mathrm{C}$, high curing temperatures accelerate the reaction process of flyash with an activator solution or the geopolymerization process that occurs in geopolymer concrete.

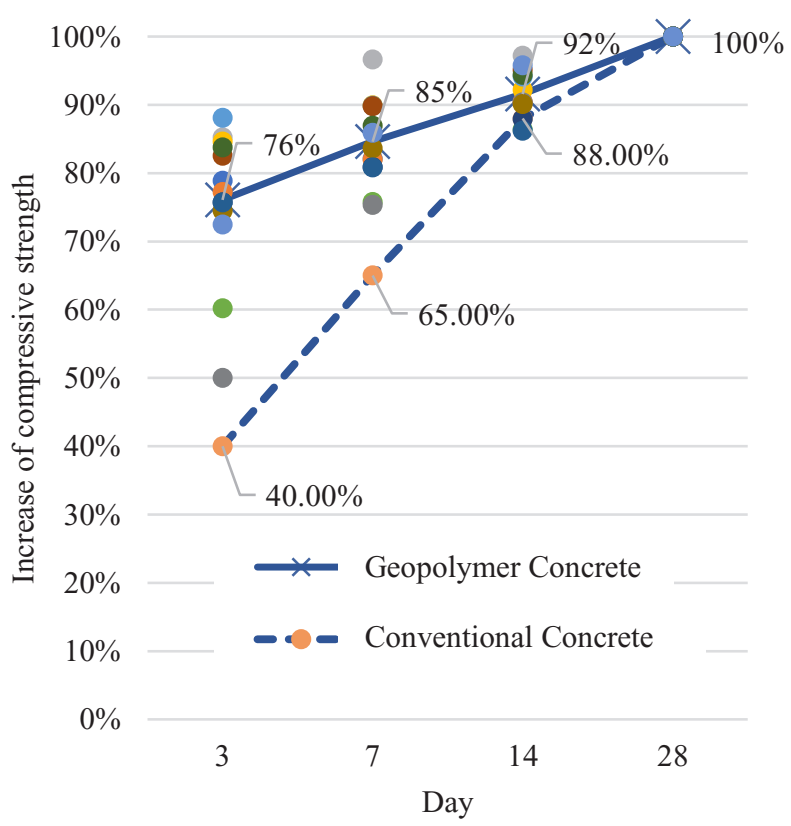

Fig. 11. Relation between additional water, compressive strength and molarity of $\mathrm{NaOH}$

\section{Conclusions}

1. SNI 6468-2000 can be used to make the initial mix design of geopolymer concrete with several modifications.

2. The increase in additional water in the manufacture of geopolymer concrete will also increase the value of slump.

3. At a certain limit the use of additional water in the manufacture of concrete will increase the value of slump and compressive strength.

4. The higher the $\mathrm{NaOH}$ molarity will result in a higher compressive strength value.

5. Increasing the compressive strength of geopolymer concrete at early age is higher than normal concrete.

The Author would like to acknowledge that this research is funded by Directorate for Research and Community Service, Directorate General of Research and Development Strengthening, Ministry of Research, Technology, and Higher Education of the Republic of Indonesia, No.: 021/KM/PNT/2018, 6 March 2018.

\section{References}

1. J. Davidovits, Geopolymer Chemistry \& Applications, $2^{\text {nd }}$ edition (2005)

2. H. Hardjasaputra, E. Ekawati, Research design of geopolymer concrete based on PLTU SuralayaBanten flyash on compressive and flexible strength, A scientific jurnal of civil engineering, 22, 24-33 (2018)

3. T. Glasby, J. Day, R. Genrich, J. Aldred, EFC Geopolymer concrete aircraft pavements at brisbane west wellcamp airport, $27^{\text {th }}$ Biennial National Conference of the Concrete Institute of Australia in conjunction with the 69 ${ }^{\text {th }}$ RILEM week, 1051-1059 (2015)

4. M. Al Bakri, A.M., Kamarudin, H., Bnhussain, M., Nizar, K., Rafiza, A.R., Zarina, Y. Reviews on Advanced Materials Science, 30 (1), 90-97 (2012)

5. Badan Standardisasi Nasional, SNI 03-6468-2000 Tata cara perencanaan campuran tinggi dengan semen portland dengan abu terbang (2002) 